\title{
Mortality rates in by-caught loggerhead turtle Caretta caretta in the Mediterranean Sea and implications for the Atlantic populations
}

\author{
I. Álvarez de Quevedo ${ }^{1, *}$, M. San Félix ${ }^{2}$, L. Cardona ${ }^{1}$ \\ ${ }^{1}$ Department of Animal Biology and Institut de Recerca de la Biodivesitat (IRBio), Faculty of Biology, \\ University of Barcelona, 08028 Barcelona, Spain \\ ${ }^{2}$ Vellmarí Formentera, 07870 Formentera, Spain
}

\begin{abstract}
Reliable estimates of the post-release mortality probability of marine turtles after incidental by-catch are essential for assessing the impact of longline fishing on these species. Large numbers of loggerhead turtles Caretta caretta from rookeries in the northwestern Atlantic Ocean have been by-caught annually in the southwestern Mediterranean Sea since the 1980s, but nothing is known about their post-release mortality probability under natural conditions. Pop-up archival transmitting tags were attached to 26 loggerhead turtles following incidental capture by Spanish longliners. Hooks were not removed, and $40 \mathrm{~cm}$ of line was left in place. The post-release mortality probability during the $90 \mathrm{~d}$ following release ranged from 0.308 to 0.365 , and was independent of hook location. When the post-release mortality probability was combined with previously reported estimates of the mortality probability before hauling, the aggregated by-catch mortality probability ranged from 0.321 to 0.378 . Assuming a total annual by-catch of 10656 loggerhead turtles by the Spanish longline fleet operating in the southwestern Mediterranean, bycatch results in 3421 to 4028 turtle deaths annually. This range is equivalent to $8.5-10.1 \%$ of the approximately 40000 turtles inhabiting the fishing grounds used by Spanish longliners, most of them from rookeries in the northwestern Atlantic. As a consequence, the accumulated mortality during the oceanic stage is expected to be larger for those loggerhead turtles of Atlantic origin that spend several years in the Mediterranean Sea than for turtles of the same cohort that remain in the Atlantic. For this reason, the Mediterranean can be considered a dead end for loggerhead turtle populations nesting in the Atlantic, although the actual demographic relevance of by-catch mortality of loggerhead turtles in the Mediterranean remains unknown.
\end{abstract}

KEY WORDS: Caretta caretta $\cdot$ By-catch $\cdot$ Mortality $\cdot$ Longlines $\cdot$ Mediterranean $\cdot$ Satellite tags

\section{INTRODUCTION}

Direct exploitation and incidental by-catch have depleted the populations of many large marine vertebrates worldwide (Jackson \& Sala 2001, Lewison et al. 2004a). National regulations have sometimes been effective in allowing depleted populations to rebuild (Gerber \& Hilborn 2001), but this approach can be unsuccessful for species with complex life histories involving migrations beyond national jurisdictions.

As migratory species, sea turtles represent a good example of the need for global conservation strategies because they disperse over entire oceans and use habitats 1000s of kilometers apart (Spotilla 2004). Furthermore, there are major gaps in our knowledge about the impact of by-catch on the dynamics of sea turtle populations, particularly about how many tur- 
tles are taken in each region and how many die following incidental capture (Godley et al. 2008, Hamann et al. 2010)

The loggerhead turtle Caretta caretta inhabits most of the tropical and subtropical oceans of the world (Wallace et al. 2010a), and the largest nesting aggregation of the species in the Atlantic (and one of the largest in the world) is found along the sandy coasts of North America (Ehrhart et al. 2003, Wallace et al. 2010a).

High numbers of hatchlings from these rookeries migrate eastward with the Gulf Stream to reach Europe and northwestern Africa (Laurent et al. 1993, 1998, Bolten et al. 1998). Once in the Mediterranean, young loggerhead turtles of Atlantic origin will remain there for many years due to the barrier imposed by the currents at the Straits of Gibraltar and the Alboran Sea (Revelles et al. 2007c, Eckert et al. 2008).

The eastern Mediterranean also supports a genetically distinct nesting population of loggerhead turtles (Broderick et al. 2002, Carreras et al. 2007, 2011), but loggerhead turtles of Mediterranean and Atlantic origin do not mix homogenously within the Mediterranean feeding grounds and the latter represent $>90 \%$ of the oceanic-stage loggerhead turtles found in the southwestern Mediterranean (Carreras et al. 2006, 2011, Revelles et al. 2007a).

The southwestern Mediterranean supports the most intense longline fishing activity within the whole basin (Fig. 1; Lewison et al. 2004b, Casale 2011), and the loggerhead turtle is the marine turtle most often by-caught in the area (Carreras et al. 2004, Álvarez de Quevedo et al. 2010). Spanish longliners represent the bulk of the fleet operating there, and most of the fishing effort is concentrated in the south toward the Balearic Archipelago, independent of the base port (Aguilar et al. 1993, Camiñas 1997, Carreras et al. 2004, Báez et al. 2007, Álvarez de Quevedo et al. 2010).

The Spanish longline fleet has been reported to have by-caught as many as 20000 loggerhead turtles annually since the 1980s (Mayol et al. 1988, Aguilar et al. 1995, Casale 2011), with a probability of postrelease mortality of 0.29 (Aguilar et al. 1993, 1995). These figures have raised international concern (Wallace et al. 2010b) and suggest that the Spanish longline fishing fleet might have killed approximately 5800 turtles annually since the early 1980s, equivalent to $14.5 \%$ of the 40000 turtles inhabiting the fishing grounds in the southwestern Mediterranean according to the results of aerial surveys (Cardona et al. 2005, Gómez de Segura et al. 2006). As most of the turtles inhabiting the fishing grounds used by the Spanish fleet in the southwestern Mediterranean have a northwestern Atlantic origin (Carreras et al. 2006, 2011, Revelles et al. 2007a), this is presumed to be the origin of approximately $90 \%$ of the turtles by-caught by the Spanish fleet (L. Cardona \& M. Clusa unpubl. data).
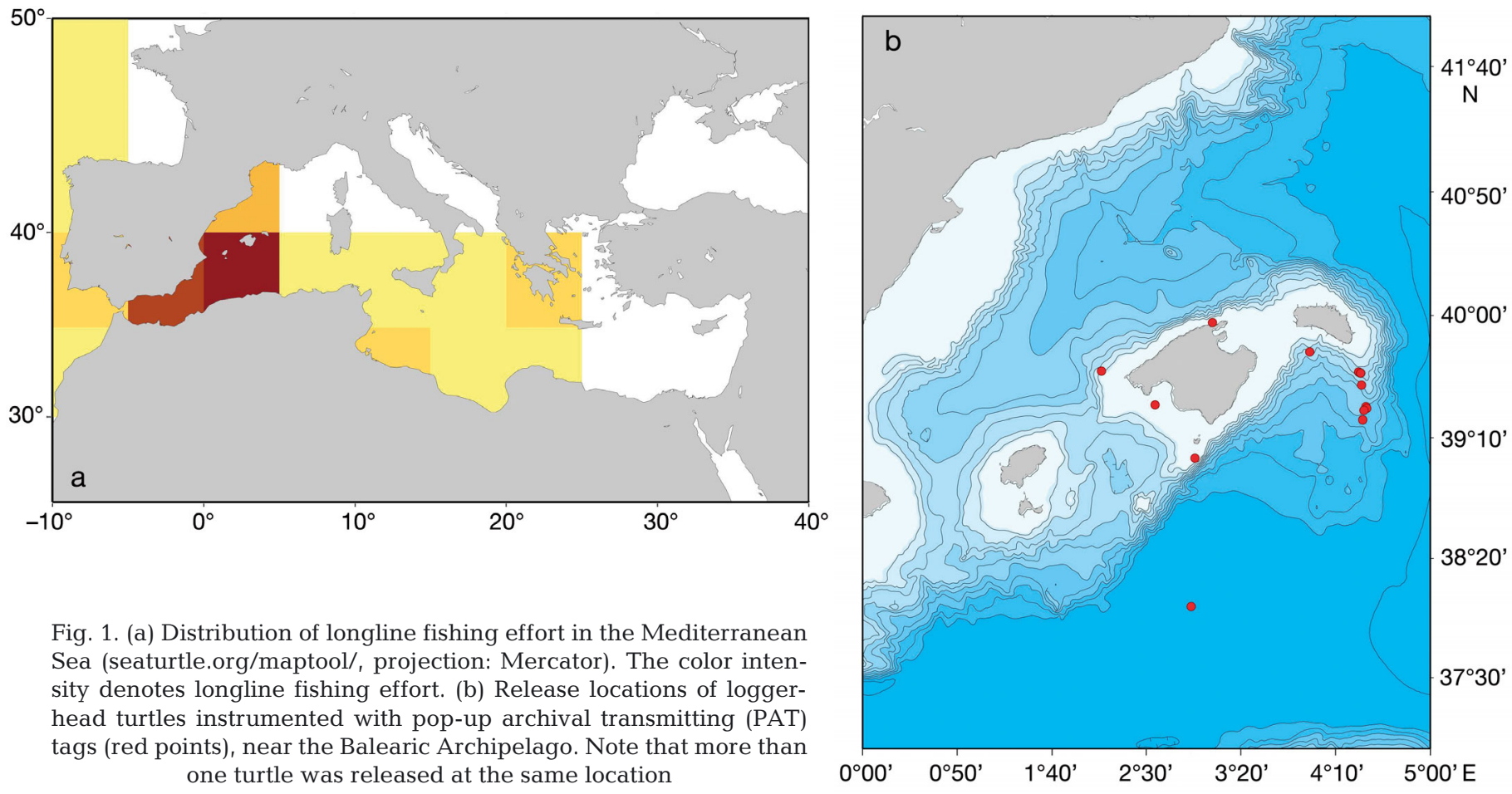

Fig. 1. (a) Distribution of longline fishing effort in the Mediterranean Sea (seaturtle.org/maptool/, projection: Mercator). The color intensity denotes longline fishing effort. (b) Release locations of loggerhead turtles instrumented with pop-up archival transmitting (PAT) tags (red points), near the Balearic Archipelago. Note that more than one turtle was released at the same location 
Accordingly, incidental by-catch in the foraging grounds in the southwestern Mediterranean could have a relevant impact on the population nesting in the northwestern Atlantic, although there are uncertainties in the above-reported figures. First, the postrelease mortality rate of by-caught turtles remains unclear, as the only available estimate is derived from hooked turtles held in captivity (Aguilar et al. 1993, 1995). Second, by-catch data collected throughout the past decade from multi-boat surveys have often yielded much lower by-catch estimates (Carreras et al. 2004, Camiñas et al. 2006, Álvarez de Quevedo et al. 2010) than those reported from earlier surveys and/or from surveys based on a single boat (Mayol et al. 1988, Aguilar et al. 1995, Camiñas 1997, Báez et al. 2007).

The objectives of the present study were to assess the post-release mortality rate, under natural conditions, of oceanic-stage loggerhead turtles incidentally by-caught by longliners operating in the southwestern Mediterranean and to calculate how many loggerhead turtles are killed annually by the Spanish longliner fleet.

\section{MATERIALS AND METHODS}

We deployed pop-up archival transmitting (PAT) tags (PAT-Mk10, Wildlife Computers) on 26 loggerhead turtles which had been incidentally caught by Spanish longliners off the Balearic Archipelago in 2007 and 2008 (Fig. 1). The turtles were hauled on board with a scoop net to avoid further damage.

The hooks were not removed, and $40 \mathrm{~cm}$ of line from the mouth was left in place. This procedure raises certain ethical issues, but we believe that it represents the only way to replicate the release of turtles by fishermen and to obtain a robust estimate of the post-release mortality probability. Control turtles were not used because a very large number of turtles had to be tracked to obtain confidence intervals sufficiently tight to detect any statistically significant differences and because using PAT tags for control turtles would have resulted in a smaller sample size for hooked turtles.

We employed a $15 \mathrm{~cm}$ tether and a base plate system to attach the PAT tags. The tether was a $2 \mathrm{~mm}$ fishing line, and the base plate was made with a plastic lattice coated with several layers of resin and fiberglass. An opening in the coating allowed the tether to be secured to the lattice (Fig. 2). Laboratory trials confirmed the positive buoyancy of the PATbase plate system.

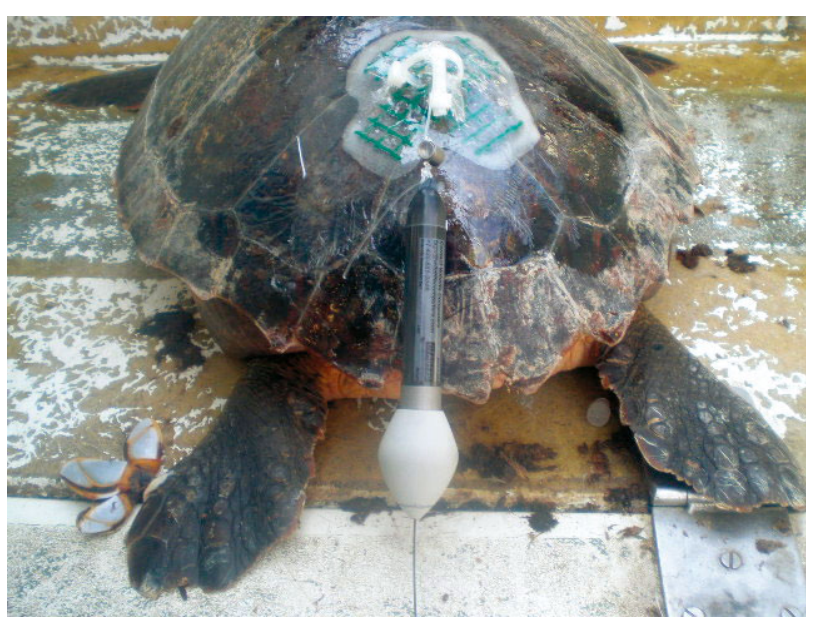

Fig. 2. Attachment system for the PAT tags used in this study

The PAT tags were programmed using PATHOST software to record pressure (i.e. depth, $\mathrm{m}$ ) and temperature $\left({ }^{\circ} \mathrm{C}\right)$ every $2 \mathrm{~s}$ and light level every $10 \mathrm{~s}$. The data were stored in 14 depth and temperature bins covering ranges from 0 to $>250 \mathrm{~m}$ (up to $500 \mathrm{~m}$ ) and 5 to $>32^{\circ} \mathrm{C}$, respectively. This procedure was based on observations that turtles that die in captivity initially sink (Swimmer et al. 2006) and that loggerhead turtles never dive deeper than $300 \mathrm{~m}$ (Lutcavage \& Lutz 1997). The PAT tags were also programmed to release and transmit data if they did not experience significant pressure changes for $192 \mathrm{~h}$, i.e. if they were shed and floating on the surface or if the turtle had died and sunk to a depth of $500 \mathrm{~m}$. Furthermore, the tags were programmed to release when they reached a depth of $1500 \mathrm{~m}$. In addition, to avoid reaching a depth that would crush the recording system in the case of a sinking turtle and failure of the premature release programming, a device (RD-1800; Wildlife Computers) was attached to sever the tether if the tag descended below $1800 \mathrm{~m}$.

The PAT tag data were used to classify tagged turtles according to 3 possible outcomes: (1) 'alive' (scheduled), representing turtles who survived the entire duration of the planned deployment; (2) 'inconclusive' (prematurely released), representing turtles of unknown fate (e.g. the tag became detached or popped up before the expected date for an unknown reason); or (3) 'dead' (prematurely released), turtles presumed to be dead (e.g. the tag remained at a constant depth for the programmed premature release period or sank below $1500 \mathrm{~m}$ ).

Although the PAT tags were programmed to release from the turtle $120 \mathrm{~d}$ after deployment and archive data for this period, we right-censored the 
data and included in the study only the first $90 \mathrm{~d}$ after deployment. Most hooked turtles actually die during the first 3 mo after release (Aguilar et al. 1993, Chaloupka et al. 2004), and expanding the study period would have confounded the mortality resulting from by-catch with that resulting from natural causes.

The survival rate (throughout the $90 \mathrm{~d}$ of tracking) was calculated using 2 different methods. First, the mortality probability of the tagged turtles was calculated as the ratio of 'alive' plus 'inconclusive' turtles to the total number of turtles tagged, and bootstrapping was used to calculate the $95 \%$ confidence intervals of this estimate by sampling 26 turtles randomly from our data base to generate 1000 simulated surveys. Furthermore, a chi-squared test was used to compare the mortality probability of those turtles hooked in the jaw or the mouth and those hooked in the esophagus or the stomach. The 'alive' and the 'inconclusive' turtles were merged for those analyses because most of the latter were thought to be alive when the PAT tags released prematurely. This conclusion was based on the comparison of the diving behavior of the 3 groups of turtles ('alive', 'dead' and 'inconclusive').

Raw dive and time data were collected by PAT tags as frequency histograms based on predefined depth and duration bins programmed into the transmitter prior to deployment. These histograms were aggregated over several hours for transmission, and we received on average 4 of those aggregated data sets for every tracking day. This information was used to create an average time-depth histogram for each group of turtles, and the histogram of the 'inconclusive' turtles was latter compared with that of the other 2 groups using a Kolmogorov-Smirnov test (Zar 1984). Furthermore, the average time at surface and the average maximum dive-depth of each individual turtle during the whole tracking period were calculated. Average time at surface was calculated as the average daily percentage of time spent at the $0 \mathrm{~m}$ bin, and average maximum dive-depth was calculated as the average depth of the deepest daily dives. These parameters are widely used to characterize turtle diving behavior (Polovina et al. 2003, Swimmer et al. 2006, Hochscheid et al. 2010, Howell et al. 2010). The gross average of each of those parameters was computed for each group of turtles and compared using ANOVA, after checking for normality and homoscedasticity using Lilliefors and Levene tests, respectively (Zar 1984).

For the second approach, we followed the example of Sasso et al. (2011) and used the capture histories of the tagged turtles to estimate survival at the end of the $90 \mathrm{~d}$ tracking period, using the known fate model in the program MARK (White \& Burnham 1999). We ran 4 models in MARK, considering survival as constant over time (survival being the same in each week after release) and survival by time period (survival varying by week) and considering hook location (mouth vs. internal) or ignoring hook location. We used Akaike's information criterion adjusted for small sample sizes (AICc) to rank the models and determine which model best fit the data (Hurvich \& Tsai 1989, Burnham \& Anderson 1992, 1998). When comparing models using AICc, a difference of $<2$ in AICc values indicates no real difference, a difference between 2 and 7 indicates considerable support for a difference, and a difference of $>7$ indicates strong support for a difference between the models (Burnham \& Anderson 1998).

In both approaches, the post-release mortality probability derived from the PAT tags experiment was combined with the hauling mortality probability reported by Camiñas et al. (2006) to calculate the aggregated mortality.

Data from Carreras et al. (2004) and Álvarez de Quevedo (2010) were used to estimate the turtle bycatch by the Spanish fishing fleet and combined with the aggregated mortality to calculate the total number of turtles that die annually as a result of interactions with the Spanish longliner fleet. Spanish longliners operating in the Mediterranean between 2001 and 2006 included 184 vessels (www.magrama. gob.es/es/estadistica/temas/estadisticas-pesqueras/ 2012_01_Buques_eslora_tcm7-194379.pdf), but only 105 used drifting longlines (Carreras et al. 2004, Báez et al. 2007).

\section{RESULTS}

The 26 turtles tagged ranged in size from 43 to $60 \mathrm{~cm}$ curved carapace length (CCL). A total of 16 turtles were hooked in the jaw or the mouth (classified as 'mouth'), and 10 turtles were hooked in the esophagus or the stomach (classified as 'internal').

Turtles were usually released a few hours after tag attachment, but one of them was retained on board because it was very weak and finally died on the deck of the longliner $15 \mathrm{~h}$ after being captured and tagged. The remaining 25 turtles were released alive, and their PAT tags reported data within the 3 mo following deployment (Table 1).

Nine turtles were classified as 'alive' at the end of the entire programmed tracking period because their PAT tags were released as scheduled. The PAT tags 
Table 1. Caretta caretta. Characteristics of satellite-tracked loggerhead turtles. CCL: curved carapace length; PAT: pop-up archival transmitting

\begin{tabular}{|c|c|c|c|c|c|c|}
\hline Turtle & $\begin{array}{l}\text { Capture } \\
\text { month }\end{array}$ & $\begin{array}{l}\text { CCL } \\
(\mathrm{cm})\end{array}$ & $\begin{array}{c}\text { Hook } \\
\text { position }\end{array}$ & $\begin{array}{c}\text { Tracking days } \\
+ \text { days } \\
\text { at surface }\end{array}$ & $\begin{array}{l}\text { PAT tag } \\
\text { release }\end{array}$ & $\begin{array}{l}\text { Classi- } \\
\text { fication }\end{array}$ \\
\hline 12007 & Sep & 54 & Mouth & 90 & Scheduled & Alive \\
\hline 22007 & Sep & 45 & Mouth & $45+8$ & Premature & Alive \\
\hline 32007 & Sep & 43 & Internal & $85+8$ & Premature & Alive \\
\hline 42007 & Sep & 53 & Internal & 90 & Scheduled & Alive \\
\hline 52007 & Sep & 62 & Internal & 0 & Dead on board & Dead \\
\hline 62007 & Sep & 58 & Internal & $58+8$ & Premature & Alive \\
\hline 72007 & Sep & 63 & Mouth & 90 & Scheduled & Alive \\
\hline 82007 & Sep & 54 & Internal & 22 & $192 \mathrm{~h} />250 \mathrm{~m}$ & Dead \\
\hline 92007 & Sep & 50 & Internal & 90 & Scheduled & Alive \\
\hline 102007 & Sep & 51 & Mouth & 90 & Scheduled & Alive \\
\hline 112007 & Sep & 60 & Internal & $73+8$ & Premature & Alive \\
\hline 122007 & Sep & 64 & Mouth & 90 & Scheduled & Alive \\
\hline 132007 & Sep & 58 & Internal & 90 & Scheduled & Alive \\
\hline 142007 & Sep & 61 & Internal & 90 & Scheduled & Alive \\
\hline 12008 & Jul & 69 & Mouth & $74+8$ & $1500 \mathrm{~m}$ & Dead \\
\hline 22008 & Jul & 49 & Mouth & 25 & $192 \mathrm{~h} />250 \mathrm{~m}$ & Dead \\
\hline 32008 & Jul & 53 & Internal & $13+8$ & $1500 \mathrm{~m}$ & Dead \\
\hline 42008 & Jul & 50 & Mouth & $25+8$ & $1500 \mathrm{~m}$ & Dead \\
\hline 52008 & Jul & 60 & Mouth & $87+8$ & Premature & Alive \\
\hline 62008 & Jul & 49 & Mouth & $54+8$ & Premature & Alive \\
\hline 72008 & Jul & 58 & Mouth & $70+8$ & Premature & Alive \\
\hline 82008 & Jul & 59 & Mouth & $77+8$ & Premature & Alive \\
\hline 92008 & Jul & 53 & Mouth & $25+8$ & Premature & Alive \\
\hline 102008 & Jul & 66 & Mouth & $1+8$ & $192 \mathrm{~h} />250 \mathrm{~m}$ & Dead \\
\hline 112008 & Jul & 63 & Mouth & 90 & $1500 \mathrm{~m}$ & Dead $^{\mathrm{a}}$ \\
\hline 122008 & Jul & 58 & Mouth & 90 & Scheduled & Alive \\
\hline
\end{tabular}

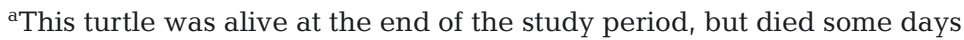
later, and we considered it as dead

suggesting that these turtles were not dead.

The average time-depth histogram of the 'inconclusive' turtles was significantly different from those of the 'alive' and 'dead' turtles and intermediate between them (Fig. 3; Komogorov-Smirnov; alive-inconclusive: $d_{14,562}=67$; dead-inconclusive: $d_{14,562}=34 ; \mathrm{p}<0.001$ in both cases). The 3 groups of turtles did not differ in time at surface (Fig. 4; ANOVA, $F_{2,22}=1.582$, $p=0.230$ ), but the average maximum dive-depth of the 'inconclusive' turtles did not differ from that of the 'alive' turtles and was much deeper than that of the 'dead' turtles (Fig. 4; ANOVA, $F_{2,22}=$ 5.159, $\mathrm{p}=0.016)$. Based on these results, we concluded that the diving behavior of the turtles classified as 'inconclusive' was closer to that of the 'alive' turtles; hence, they were most likely alive when the PAT tags were prematurely released.

Accordingly, 8 of the 26 turtles tagged were considered to have died during the $90 \mathrm{~d}$ after hooking: the turtle that died while on deck and the 7 turtles that remained at a constant depth for $192 \mathrm{~h}$ or sank to

of the other 16 turtles were released prematurely. Seven of them were certainly dead (and were accordingly classified as 'dead'); 3 of them sank deeper than $250 \mathrm{~m}$ and remained there for $192 \mathrm{~h}$, when the PAT tags were released and transmitted; and the other 4 PAT tags were released when turtles sank to $1500 \mathrm{~m}$. The reasons for the premature release of the 9 other PAT tags were unknown; hence, they were classified as 'inconclusive'.

Some data error related to tracking and/or release dates occurred for all of those 9 PAT tags, but these errors were unlikely to have affected the accuracy of the data related to depth and temperature or to have caused premature release. Moreover, 5 of these PAT tags were released after a relatively deep dive (100 to $150 \mathrm{~m}$ ), suggesting a failure of the attachment system due to pressure or the drag caused by deep-diving acceleration,

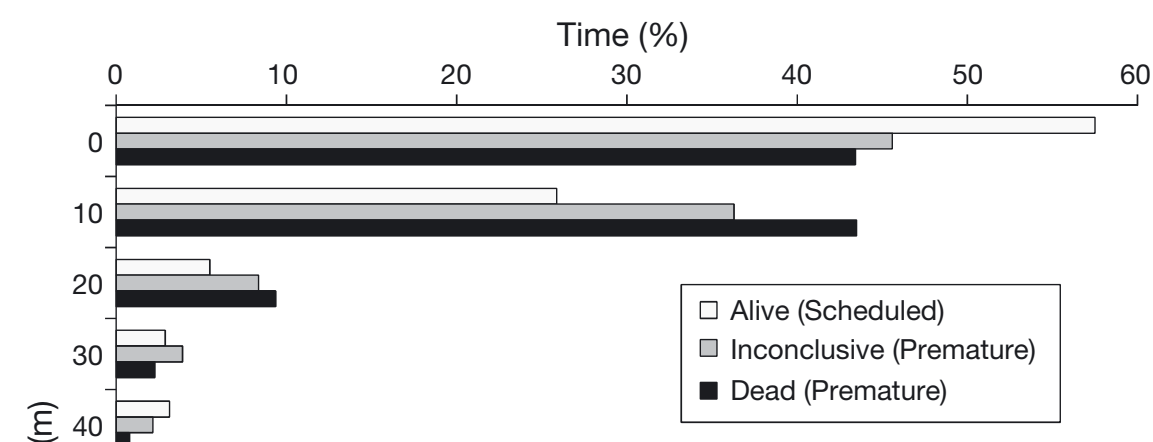

Fig. 3. Caretta caretta. Time-depth data for 26 loggerhead turtles incidentally by-caught with longlines and instrumented with PAT tags before release. The bars show the average time spent in each depth range. Three groups of turtles were compared, based on their fate after $90 \mathrm{~d}$ of tracking: 'alive' ( $\mathrm{n}=9$ ), 'inconclusive' $(\mathrm{n}=9)$ and 'dead' $(\mathrm{n}=8)$ 

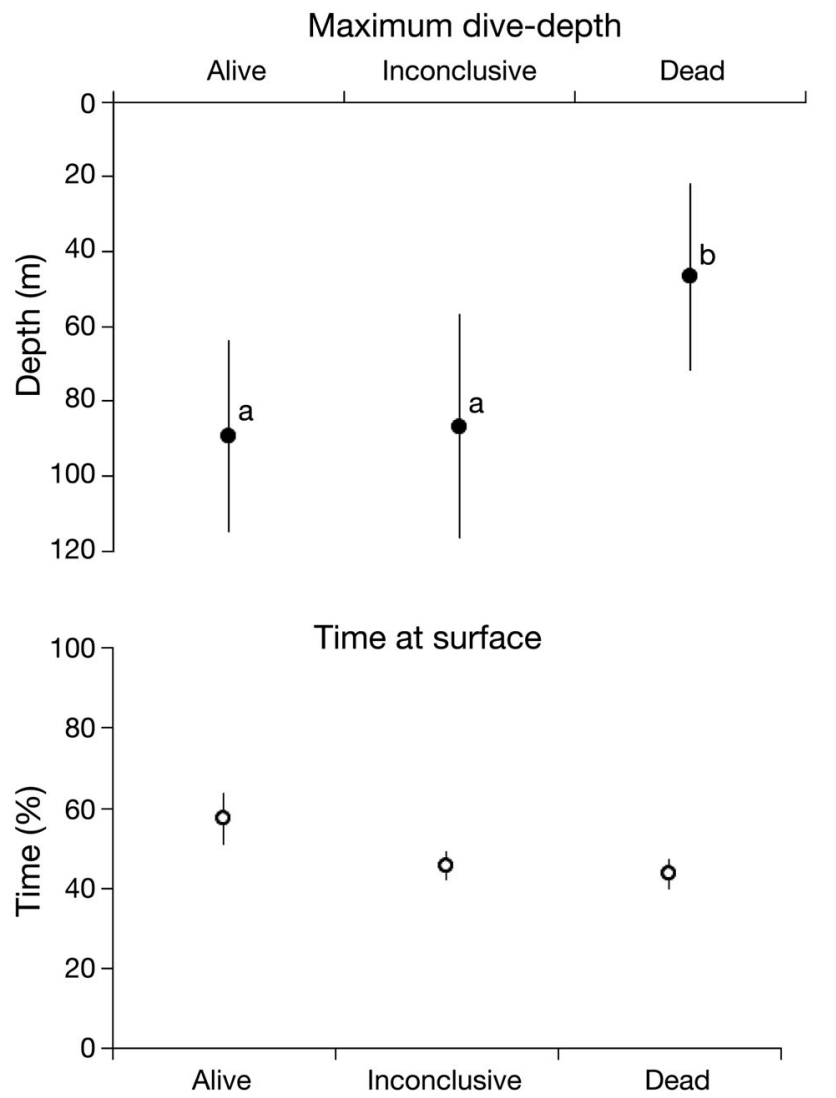

Fig. 4. Caretta caretta. Mean $\pm \mathrm{SD}$ 'maximum dive-depth' and 'time at surface' of 3 groups of loggerhead turtles incidentally by-caught with longlines and instrumented with PAT tags before release. Turtles were classified by their fate after $90 \mathrm{~d}$ of tracking as 'alive' ( $\mathrm{n}=9$ ), 'inconclusive' $(\mathrm{n}=9)$ or 'dead' $(n=8)$. Different lower case letters denote statistically significant differences

effect on the proportions of turtles alive or dead at the end of the tracking period (chi-squared $=0.030, \mathrm{df}=$ $1, \mathrm{p}=0.862$ ): 5 of the 16 turtles with hooks in the 'mouth' and 3 of the 10 turtles with 'internal' hooks died during the tracking period (Table 1). The aggregated by-catch mortality probability was 0.321 .

The analysis of these data using the MARK program yielded results similar to those reported above. On the one hand, the $90 \mathrm{~d}$ post-release mortality probability was 0.365 (95\% CI: 0.105 to 0.576 ) and was best modeled as time- and hook-location-invariant $(\mathrm{AICC}=72.9$ with an $\mathrm{AICC}$ weight $=0.732$ vs. $\mathrm{AICc}=74.9$ with an AICc weight $=0.265$ for the timeinvariant, hook-location-dependent model; $\mathrm{AICc}=$ 84.1 with an AICc weight $=0.003$ for the time-dependent, hook-location-invariant model; and $\mathrm{AICc}=$ 113.4 with an AICc weight $=0.000$ for the time- and hook-location-dependent model). The aggregated by-catch mortality probability calculated using this approach was 0.378 . On the other hand, the analysis run as a best-case scenario (assuming that all the censored turtles survived for $90 \mathrm{~d}$ ) was also best modeled as time- and hook-location-invariant $(\mathrm{AICC}=$ 75.3 with an $\mathrm{AICc}$ weight $=0.729 \mathrm{vs}$. AICC $=77.4$ with an AICc weight $=0.266$ for the time-invariant, hooklocation-dependent model; $\mathrm{AICC}=85.5$ with an AICc weight $=0.004$ for the time-dependent, hook-location-invariant model; and $\mathrm{AICC}=114.2$ with an $\mathrm{AICC}$ weight $=0.000$ for the time- and hook-locationdependent model) with an estimate mortality probability of 0.323 (95\% CI: 0.171 to 0.523 ). The calculated aggregated by-catch mortality probability was 0.346 .

Álvarez de Quevedo et al. (2010) collected data on turtle catch per unit effort and fishing effort from 15 vessels throughout the fishing season and reported an average annual turtle catch of 102 turtles vessel ${ }^{-1}$. The extrapolation of this value to the entire fleet yields an estimated total annual by-catch of 10656 turtles, equivalent to 3421 to 4028 turtles killed annually by the Spanish fleet of longliners when the aggregated by-catch mortality probability estimates reported above (0.321 to 0.378 ) are considered.

\section{DISCUSSION}

The results of the present study suggest that the post-release mortality probability of monitored loggerhead turtles during the $90 \mathrm{~d}$ following their release ranged from 0.308 to 0.365 , depending on the calculation approach used, and was independent of hook location. When the post-release mortality probability was combined with the previously reported estimates of the mortality probability before hauling, the aggregated by-catch mortality probability ranged from 0.321 to 0.378 . Assuming a total bycatch of 10656 loggerhead turtles $\mathrm{yr}^{-1}$, these figures indicate that the Spanish longline fleet operating in the southwestern Mediterranean may have killed 3421 to 4028 turtles annually during the 2000s. These figures are lower than the estimate of 5800 turtles killed annually, according to early reports (Aguilar et al. 1993, 1995), mainly because total by-catch figures from more recent reports are lower (Carreras et al. 2004, Alvarez de Quevedo et al. 2010).

Satellite tracking and conventional tagging have revealed that most of the loggerhead turtles in the southwestern Mediterranean remain throughout the year within the Algerian Basin, a region limited by the Balearic Archipelago, Sardinia, northern Africa and southwestern Spain, whereas those in the 
Balearic Sea, the region between southern France, the Balearic Archipelago and eastern Spain, remain there year-round or move to the Algerian Basin (Cardona et al. 2005, Revelles et al. 2007b, Eckert et al. 2008, Revelles et al. 2008). Accordingly, the density figures derived by combining aerial surveys with surfacing behavior revealed by satellite tracking (Cardona et al. 2005, Gómez de Segura et al. 2006) can be used to calculate an estimate of approximately 40000 turtles within the oceanic habitats supporting the activity of the Spanish longline fleet. If this calculation is correct, the total number of loggerhead turtles killed annually by the Spanish fleet of longliners represents approximately 8.5 to $10.1 \%$ of the oceanic turtles in the Algerian Basin and the Balearic Sea.

However, this estimate is sensitive to some methodological issues with the use of PAT tags that deserve careful consideration. PAT tags are programmed for premature release when turtles exhibit anomalous diving patterns suggestive of turtle death, such as very deep dives (>1500 m) or very long periods at a constant depth. However, PAT tags may also release prematurely if the tether breaks up because of drag or predation (Sasso et al. 2011). Since the reason for premature release is unknown, the actual fate of those turtles and the actual mortality rate is uncertain, because, even if 'inconclusive' turtles were alive when PAT tags were released prematurely, we ignored their fate after release. Double tagging would avoid these shortcomings, but this approach is infeasible due to the high cost of PAT tags.

Analysis of diving behavior offers an alternative method of determining the fate of those turtles whose PAT tags were prematurely released for unknown reasons, because injured turtles often experience buoyancy problems, which may persist even after rehabilitation (Cardona et al. 2012). Although each of the 3 groups of turtles considered differed in their time-depth distribution patterns, the maximum divedepth reached by the 'inconclusive' turtles was not different from that reached by the surviving ('alive') turtles and was much greater than that of the dead turtles. The time at surface was not informative, as the differences were not statistically significant. Hence, we can conclude that most of the 'inconclusive' turtles were likely to have been alive when the PAT tag was released prematurely, although the possibility that some of them were dead cannot be excluded completely. The conclusion that most of the 'inconclusive' turtles were alive when the PAT tag was released prematurely is also supported by the similarity of the mortality probabilities resulting from considering the 'inconclusive' turtles alive and the output of the MARK program, which considers only the known-fate turtles (dead or alive).

Limiting the tracking period to $90 \mathrm{~d}$ may have also led to underestimation of the post-release mortality rate, although the available evidence indicates that most hooked turtles die within 3 mo after hooking (Aguilar et al. 1993, Chaloupka et al. 2004), and most, but not all, of the turtles monitored in this study died in the first month after release. It should be noted that tagged turtles may also die during tracking due to predator attacks or a second incidental by-catch event (Swimmer et al. 2006, Sasso \& Epperly 2007, Sasso et al. 2011). As a consequence, increasing the tracking time to $>90 \mathrm{~d}$ could have resulted in overestimation of the post-release mortality rate, as other mortality sources would be included. We cannot exclude the possibility that some of the turtles tracked for $90 \mathrm{~d}$ died for reasons other than longline interaction, but the fact that most died in the first month after release strongly suggests that mortality was not randomly distributed over time, although the model that best fitted the data was time invariant.

Even with these caveats, and assuming that we offer an estimate of the minimum post-release mortality probability, the figures reported here are much higher than those reported in other studies in which PAT tags have been used (Swimmer et al. 2006, Sasso \& Epperly 2007). On the other hand, the results are similar to those obtained in a study in which hooked turtles were kept in captivity after by-catch (Aguilar et al. 1993, 1995). Differences in the PAT tag attachment methods are unlikely to have caused the observed differences in the post-release mortality probability, as mortality was low when the PAT tag tethers were attached to bolts secured to bones underlying the carapace scutes (Sasso \& Epperly 2007) and also when attached to a base plate secured to scutes with epoxy (Swimmer et al. 2006). Conversely, studies in which tag tethers were attached to base plates secured to scutes with a fixative yielded both low (Swimmer et al. 2006) and high mortality rates (present study).

In some previous studies, the hook and line have been removed from turtles hooked in the mouth (Chaloupka et al. 2004, Swimmer et al. 2006, Sasso \& Epperly 2007), but, in others, the hook was left in place, together with a piece of line spanning from the hook to the turtle beak in internally hooked turtles (Chaloupka et al. 2004). Hook removal consistently resulted in a low mortality probability after release (Chaloupka et al. 2004, Swimmer et al. 2006, Sasso \& Epperly 2007), whereas leaving hooks in place con- 
sistently resulted in a higher mortality probability (Aguilar et al. 1995, Chaloupka et al. 2004, present study). Although hook size and the point of attachment to the gastrointestinal tract could be relevant to turtle survival, the data reported here do not reveal any significant difference in the post-release mortality probability of turtles hooked in the jaw or the mouth and turtles hooked in the esophagus or the stomach. The presence of a long monofilament is most likely the single most crucial factor that determines a turtle's fate after by-catch, because strangulations and tractions produced by the line throughout the gastrointestinal tract result in lethal injuries more often than hook action (Valente et al. 2007, Casale et al. 2008, Alessandro \& Antonello 2010, Parga 2012). The results reported here strongly support this hypothesis and suggest that the use of hook types that are less likely to be swallowed but do not reduce by-catch will not result in a lower mortality rate, unless hooks lodged in the mouth can be easily removed onboard (Parga 2012). Furthermore, the evidence presented here indicates that line cutters are most likely useless in reducing post-release mortality, as the line left will usually be longer than the $40 \mathrm{~cm}$ used in this study.

The high levels of incidental mortality reported here may have consequences well beyond the Mediterranean, as available genetic data indicate a very high prevalence of turtles of northwestern Atlantic origin in the fishing grounds used by the Spanish fleet (Carreras et al. 2006, 2011, Revelles et al. 2007a) and in the by-catch of Spanish longliners (L. Cardona \& M. Clusa unpubl. data). Furthermore, loggerhead turtles entering the Mediterranean are expected to move to neritic habitats in the northwestern Atlantic at a much higher age than those of the same cohort that remain in the Atlantic, because, once they are in the Mediterranean, they grow more slowly (Bjorndal et al. 2003, Piovano et al. 2011), and because the currents at the Straits of Gibraltar and the Alboran Sea keep them in the Mediterranean until they are, on average, $58.8 \mathrm{~cm}$ CCL or $20 \mathrm{yr}$ old (Revelles et al. 2007a, Piovano et al. 2011). Furthermore, once turtles leave the Mediterranean, they spend approximately an additional year crossing the North Atlantic, although only a few turtles have been satellite-tracked during such a trip (Cejudo et al. 2006, Eckert et al. 2008).

This means that turtles of northwestern Atlantic origin entering the Mediterranean when $2 \mathrm{yr}$ old (Piovano et al. 2011) will settle into the foraging grounds in the northwestern Atlantic 13 yr later, on average, than members of the same cohort that remain in the Atlantic (Scott et al. 2012). This time lag will be shorter for turtles that enter the Mediterranean at a higher age and larger size, but, in this study, we ignored the length distribution of recently entered turtles. Nevertheless, the protracted oceanic stage of loggerhead turtles of northwestern Atlantic origin entering the Mediterranean means that they will remain exposed to high levels of incidental mortality for a much longer time. The actual relevance of this phenomenon for the northwestern Atlantic management unit will depend on the proportion of loggerhead turtles of North American origin entering the Mediterranean, a quantity that is currently unknown.

Acknowledgements. This project was partially supported by 'Fundació La Caixa' and 'Ministerio de Ciencia e Innovación del Gobierno de España' (Project CGL2009-10017). Turtles were instrumented under Permit 15664/2007, issued by Conselleria de Medi Ambient del Govern de les Illes Balears. The authors are grateful to O. Jerez, skipper of the fishing vessel 'Joana', and all fishermen involved in this project, for their assistance in deployment of PAT tags. The authors acknowledge the use of the Maptool program, a product of SEATURTLE.ORG, for the maps in this paper (information is available at www.seaturtle.org).

\section{LITERATURE CITED}

Aguilar R, Mas J, Pastor X (1993) Las Tortugas marinas y la pesca con palangre de superficie en el Mediterráneo. Greenpeace, Palma de Mallorca

Aguilar R, Mas J, Pastor X (1995) Impact of the Spanish swordfish longline fisheries on the loggerhead sea turtle Caretta caretta population in the western Mediterranean. In: Richardson JI, Richardson TH (eds) Proc 12th annual workshop on sea turtle biology and conservation, Jekyll Island, GA, 25-29 Feb 1992. NOAA Tech Memo NMFS-SEFSC-361, p 1-6

> Alessandro L, Antonello S (2010) An overview of loggerhead sea turtle (Caretta caretta) bycatch and technical mitigation measures in the Mediterranean Sea. Rev Fish Biol Fish 20:141-161

Álvarez de Quevedo I, Cardona L, De Haro A, Pubill E, Aguilar A (2010) Sources of bycatch of loggerhead sea turtles in the western Mediterranean other than drifting longlines. ICES J Mar Sci 67:677-685

> Báez JC, Real R, García-Soto C, De La Serna JM, Macías D, Camiñas JA (2007) Loggerhead turtle by-catch depends on distance to the coast, independent of fishing effort: implications for conservation and fisheries management. Mar Ecol Prog Ser 338:249-256

Bjorndal KA, Bolten AB, Dellinger T, Delgado C, Martins HR (2003) Compensatory growth in oceanic loggerhead sea turtles: response to a stochastic environment. Ecology 84 : 1237-1249

Bolten AB, Bjorndal KA, Martins HR, Dellinger T, Biscoito MJ, Encalada SE, Bowen BW (1998) Transatlantic developmental migrations of loggerhead sea turtles demonstrated by mtDNA sequence analysis. Ecol Appl 8:1-7 
Broderick AC, Glen F, Godley BJ, Hays GC (2002) Estimating the size of nesting populations of green and loggerhead turtles in the Mediterranean. Oryx 36:227-236

Burnham KP, Anderson DR (1992) Data-based selection of an appropriate biological model: the key to modern data analysis. In: MucCullough DR, Barett RH (eds) Wildlife 2001: populations. Elsevier Applied Science, New York, NY, p 16-30

Burnham KP, Anderson DR (1998) Model selection and inference: a practical information theoretic approach. Springer-Verlag, New York, NY

Camiñas JA (1997) Capturas accidentales de tortuga boba (Caretta caretta, L. 1758) en el Mediterránio occidental en la pesquería de palangre de superficie de pez espada (Xiphias gladius L.). Int Comm Conserv Atl Tuna. Coll Vol Sci Pap 46:446-455

> Camiñas JA, Báez JC, Valeiras X, Real R (2006) Differential loggerhead by-catch and direct mortality due to surface longlines according to boat strata and gear type. Sci Mar 70:661-665

Cardona L, Revelles M, Carreras C, San Félix M, Gazo M, Aguilar A (2005) Western Mediterranean immature loggerhead turtles: habitat use in spring and summer assessed through satellite tracking and aerial surveys. Mar Biol 147:583-591

> Cardona L, Fernández G, Revelles M, Aguilar A (2012) Readaptation to the wild of rehabilitated loggerhead sea turtles (Caretta caretta) assessed by satellite telemetry. Aquat Conserv 22:104-112

Carreras C, Cardona L, Aguilar A (2004) Incidental catch of the loggerhead turtle Caretta caretta off the Balearic Islands (western Mediterranean). Biol Conserv 117: 321-329

Carreras C, Pont S, Maffucci F, Pascual M and others (2006) Genetic structuring of immature loggerhead sea turtles (Caretta caretta) in the Mediterranean Sea reflects water circulation patterns. Mar Biol 149:1269-1279

> Carreras C, Pascual M, Cardona L, Aguilar A and others (2007) The genetic structure of the loggerhead sea turtle (Caretta caretta) in the Mediterranean Sea revealed by nuclear and mitochondrial DNA and its conservation implications. Conserv Genet 8:761-775

> Carreras C, Pascual M, Cardona L, Marco A and others (2011) Living together but remaining apart: Atlantic and Mediterranean loggerhead sea turtles (Caretta caretta) in shared feeding grounds. J Hered 102:666-677

Casale P (2011) Sea turtle by-catch in the Mediterranean. Fish Fish 12:299-316

Casale P, Freggi D, Rocco M (2008) Mortality induced by drifting longline hooks and branchlines in loggerhead sea turtles, estimated through observation in captivity. Aquat Conserv 18:945-954

Cejudo D, Varo-Cruz N, Liria A, Castillo JJ, Bellido JJ, López-Jurado LF (2006) Transatlantic migration of juvenile loggerhead turtles (Caretta caretta) from the Strait of Gibraltar. Mar Turtle Newsl 114:9-11

Chaloupka M, Parker D, Balazs G (2004) Modelling postrelease mortality of loggerhead sea turtles exposed to the Hawaii-based pelagic longline fishery. Mar Ecol Prog Ser 280:285-293

> Eckert SA, Moore JE, Dunn DC, Sagarminaga R, Eckert KL, Halpin PN (2008) Modeling loggerhead turtle movement in the Mediterranean: importance of body size and oceanography. Ecol Appl 18:290-308

Ehrhart LM, Bagley DA, Redfoot WE (2003) Loggerhead tur- tles in the Atlantic Ocean: geographic distribution, abundance, and population status. In: Bolten A, Witherington BE (eds) Loggerhead sea turtles. Smithsonian Books, Washington, DC, p 157-174

> Gerber LR, Hilborn R (2001) Catastrophic events and recovery from low densities in populations of otariids: implications for risk of extinction. Mammal Rev 31:131-150

> Godley BJ, Blumenthal JM, Broderick AC, Coyne MS, Godfrey MH, Hawkes LA, Witt MJ (2008) Satellite tracking of sea turtles: Where have we been and where do we go next? Endang Species Res 4:3-22

Gómez de Segura A, Tomás J, Pedraza SN, Crespo EA, Raga JA (2006) Abundance and distribution of the endangered loggerhead turtle in Spanish Mediterranean waters and the conservation implications. Anim Conserv 9:199-206

Hamann M, Godfrey MH, Seminoff JA, Arthur K and others (2010) Global research priorities for sea turtles: informing management and conservation in the 21st century. Endang Species Res 11:245-269

> Hochscheid S, Bentivegna F, Hamza A, Hays GC (2010) When surfacers do not dive: multiple significance of extended surface times in marine turtles. J Exp Biol 213: 1328-1337

Howell EA, Dutton PH, Polovina JJ, Bailey H, Parker DM, Balazs JH (2010) Oceanographic influences on the dive behavior of juvenile loggerhead turtles (Caretta caretta) in the North Pacific Ocean. Mar Biol 157:1011-1026

> Hurvich CM, Tsai CL (1989) Regression and time series model selection in small samples. Biometrika 76:297-307

Jackson JBC, Sala E (2001) Unnatural oceans. Sci Mar 65: $273-281$

Laurent L, Lescure J, Excoffier L, Bowen B and others (1993) Genetic studies of relationships between Mediterranean and Atlantic populations of loggerhead turtle Caretta caretta with a mitocondrial marker. CR Acad Sci Paris Ser III 316:1233-1239

> Laurent L, Casale P, Bradai MN, Godley BJ and others (1998) Molecular resolution of marine turtle stock composition in fishery bycatch: a case study in the Mediterranean. Mol Ecol 7:1529-1542

Lewison RL, Crowder LB, Read AJ, Freeman SA (2004a) Understanding impacts of fisheries bycatch on marine megafauna. Trends Ecol Evol 19:598-604

Lewison RL, Freeman SA, Crowder LB (2004b) Quantifying the effects of fisheries on threatened species: the impact of pelagic longlines on loggerhead and leatherback sea turtles. Ecol Lett 7:221-231

Lutcavage ME, Lutz PL (1997) Diving physiology. In: Lutz PL, Musick JA (eds) The biology of sea turtles. CRC Press, Boca Raton, FL, p 277-296

Mayol J, Muntaner J, Aguilar R (1988) Incidencia de la pesca accidental sobre las tortugas marinas en el Mediterráneo español. Bull Soc Hist Nat Balears 32:19-31

Parga ML (2012) Hooks and sea turtles: a veterinarian's perspective. Bull Mar Sci 88:731-741

> Piovano S, Clusa M, Carreras C, Giacoma C, Pascual M, Cardona L (2011) Different growth rates between loggerhead sea turtles (Caretta caretta) of Mediterranean and Atlantic origin in the Mediterranean Sea. Mar Biol 158: 2577-2587

Polovina JJ, Denise EH, Parker M, Balazs GH (2003) Divedepth distribution of loggerhead (Carretta carretta) and olive ridley (Lepidochelys olivacea) sea turtles in the central North Pacific: Might deep longline sets catch fewer turtles? Fish Bull 101:189-193 
Revelles M, Carreras C, Cardona L, Marco A and others (2007a) Evidence for an asymmetric size exchange of loggerhead sea turtles between the Mediterranean and the Atlantic trough the Straits of Gibraltar. J Exp Mar Biol Ecol 349:261-271

Revelles M, Cardona L, Aguilar A, San Felix M, Fernández G (2007b) Habitat use by immature loggerhead sea turtles in the Algerian basin (western Mediterranean): swimming behaviour, seasonality and dispersal pattern. Mar Biol 151:1501-1515

Revelles M, Isern-Fontanet J, Cardona L, San Félix M, Carreras C, Aguilar A (2007c) Mesoscale eddies, surface circulation and the scale of habitat selection by immature loggerhead sea turtles. J Exp Mar Biol Ecol 347:41-57

Revelles M, Camiñas JA, Cardona L, Parga M and others (2008) Tagging reveals limited exchange of immature loggerhead sea turtles (Caretta caretta) between regions in the western Mediterranean. Sci Mar 72:511-518

Sasso CR, Epperly SP (2007) Survival of pelagic juvenile loggerhead turtles in the open ocean. J Wildl Manag 71: 1830-1835

Sasso CR, Epperly SP, Johnson C (2011) Annual survival of loggerhead sea turtles (Caretta caretta) nesting in peninsular Florida: a cause for concern. Herpetol Conserv Biol 6:443-448

Editorial responsibility: Konstantinos Stergiou, Thessaloniki, Greece
Scott R, Marsh R, Hays GC (2012) Life in the really slow lane: loggerhead sea turtles mature late relative to other reptiles. Funct Ecol 26:227-235

Spotilla JR (2004) Sea turtles: a complete guide to their biology, behavior and conservation. John Hopkins University Press, Baltimore, MD

> Swimmer Y, Arauz R, McCracken M, McNaughton L and others (2006) Diving behavior and delayed mortality of olive ridley sea turtles Lepidochelys olivacea alter their release from longline fishing gear. Mar Ecol Prog Ser 323:253-261

- Valente ALS, Parga ML, Velarde R, Marco I, Lavin S, Alegre F, Cuenca R (2007) Fishhook lesions in loggerhead sea turtles. J Wildl Dis 43:737-741

> Wallace BP, DiMatteo AD, Hurley BJ, Finkbeiner EM and others (2010a) Regional management units for marine turtles: a novel framework for prioritizing conservation and research across multiple scales. PLoS ONE 5:e15465

Wallace B, Lewison R, McDonald S, McDonald R and others (2010b) Global patterns of marine turtle bycatch. Conserv Lett 3:131-142

White GC, Burnham KP (1999) Program MARK: survival rate estimation from both live and dead encounters. Bird Study 46S:123-139

Zar JH (1984) Biostatistical analysis. Prentice-Hall, Englewood Cliffs, NJ

Submitted: June 20, 2012; Accepted: May 16, 2013 Proofs received from author(s): August 16, 2013 